\title{
Pengaruh Larutan Belimbing Wuluh (Averrhoa bilimbi L) Sebagai Bahan Marinasi Terhadap Daya Terima Daging Kambing
}

\section{The Effect of Wuluh Starfruit (Averrhoa bilimbi L) Solution as a Marinade on the} Acceptability) of Goat Meat

\section{Dyah Wahyuni*, Fitra Yosi dan Gatot Muslim}

Program Studi Peternakan, Universitas Sriwijaya, Ogan Ilir, Sumatera Selatan 30662
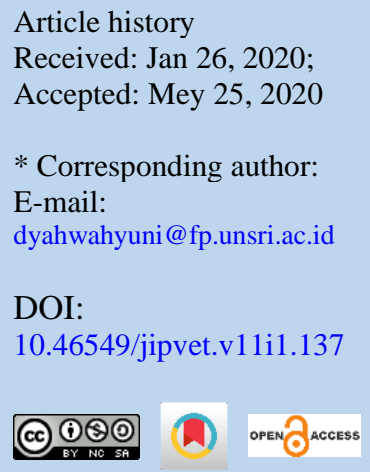

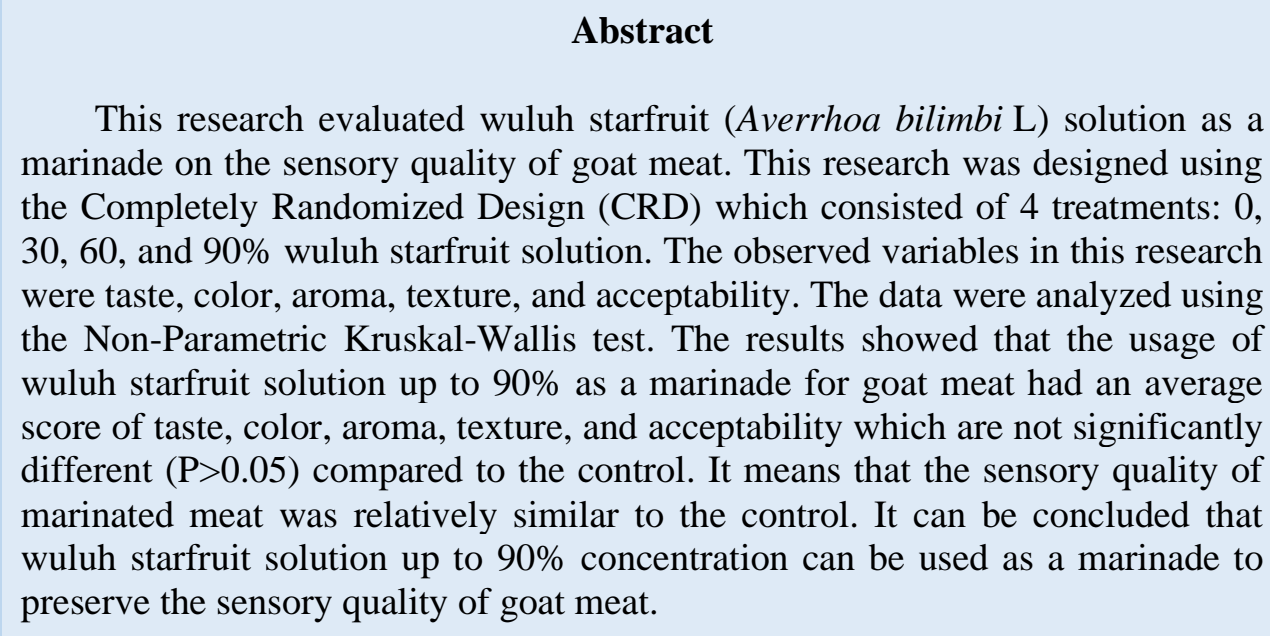

This research evaluated wuluh starfruit (Averrhoa bilimbi L) solution as a marinade on the sensory quality of goat meat. This research was designed using the Completely Randomized Design (CRD) which consisted of 4 treatments: 0, 30,60 , and $90 \%$ wuluh starfruit solution. The observed variables in this research were taste, color, aroma, texture, and acceptability. The data were analyzed using the Non-Parametric Kruskal-Wallis test. The results showed that the usage of wuluh starfruit solution up to $90 \%$ as a marinade for goat meat had an average score of taste, color, aroma, texture, and acceptability which are not significantly different $(\mathrm{P}>0.05)$ compared to the control. It means that the sensory quality of marinated meat was relatively similar to the control. It can be concluded that wuluh starfruit solution up to $90 \%$ concentration can be used as a marinade to preserve the sensory quality of goat meat.

Kata kunci: Wuluh starfruit; Goat meat; Marinade; Sensory.

\section{Abstrak}

Penelitian ini bertujuan untuk mengetahui pengaruh penggunaan larutan belimbing wuluh sebagai bahan marinasi terhadap kualitas sensoris daging kambing. Rancangan penelitian menggunakan Rancangan Acak Lengkap (RAL) dengan 4 perlakuan: 0, 30, 60 dan 90\% larutan belimbing wuluh. Peubah yang diamati dalam penelitian ini adalah rasa, warna, aroma, tekstur dan daya terima. Data dianalisa menggunakan uji hedonik Kruskal-Wallis. Hasil analisa data menunjukkan bahwa penggunaan larutan belimbing wuluh hingga $90 \%$ sebagai bahan marinasi daging kambing memiliki rerata skor rasa, warna, aroma, tekstur dan daya terima yang tidak berbeda nyata $(\mathrm{P}>0,05)$ dibandingkan kontrol. Artinya, daging yang dimarinasi memiliki kualitas sensoris yang relatif sama dengan kontrol. Berdasarkan hasil tersebut dapat disimpulkan bahwa larutan belimbing wuluh hingga $90 \%$ dapat digunakan sebagai bahan marinasi untuk mempertahankan kualitas sensoris daging kambing.

Kata kunci: Belimbing wuluh; Daging kambing; Marinasi; Sensoris

\section{PENDAHULUAN}

Daging kambing merupakan salah satu daging dari ternak ruminansia kecil yang memiliki kualitas gizi yang tidak kalah dibandingkan dengan daging dari jenis ternak yang lain. Pemeliharaan ternak kambing relatif lebih mudah karena bisa dipelihara di lahan yang relatif lebih kecil dibandingkan ternak ruminansia lain yang lebih besar. Hal ini menyebabkan daging kambing merupakan salah satu jenis daging yang banyak dikonsumsi di Indonesia. Serat daging kambing yanglebih halus dibandingkan jenis ternak ruminansia 
besar lainnya menjadikan daging kambing memiliki keempukan yang lebih baik dibandingkan daging yang berasal dari ternak ruminansia besar lainnya (Maruddin, 2004).

Aroma daging kambing merupakan hal utama dalam penerimaan daging kambing. Kandungan asam volatil (4-metiloktanat) didalam daging kambing merupakan penyebab utama bau khas yang kurang disukai. Bau khas ini muncul ketika asam lemak tersebut teroksidasi akibat paparan oksigen setelah penyembelihan (Naude et al., 1981; Wahyuni et al., 2019).Untuk mengurangi bau amis khas dari daging kambing, umumnya dilakukan marinasi terlebih dahulu sebelum diolah menggunakan enzim dari tanaman buah atau larutan asam (Pursudarsonoet al., 2015).

Belimbing wuluh (Averrhoa bilimbi L.) merupakan tanaman buah yang tumbuh baik di daerah tropis seperti Indonesia. Tanaman ini sering dijumpai di perkarangan rumah dan tumbuh liar di area ladang pertanian atau hutan dengan warna buah hijau, kuning muda dan bahkan terlihat putih (Thomas, 2007). Belimbing wuluh mengandung banyak air dan rasa yang asam yang disebabkan oleh asam sitrat sebanyak 92,6-133,8 mEq/100 g total padatan (Subhadrabandhu, 2001). Kandungan asam didalam belimbing wuluh menyebabkan bahan ini umumnya digunakan sebagai bahan marinasi untuk mengurangi bau amis daging ikan. Informasi dan literatur ilmiah mengenai penggunaan belimbing wuluh sebagai bahan marinasi daging kambing masih sangat terbatas, sehingga perlu dilakukan penelitian untuk mengetahui pengaruhnya terhadap kualitas daging kambing. Belimbing wuluh diduga dapat digunakan sebagai bahan marinasi daging kambing. Kandungan asam sitrat yang terdapat didalam belimbing wuluh diharapkan dapat mencegah oksidasi lemak daging sebelum dimasak sehingga kualitas sensoris daging dapat dipertahankan.

\section{BAHAN DAN METODE}

Bahan

Bahan yang akan digunakan pada penelitian ini yaitu daging kambing PE (Peranakan Etawa) jantan yang berumur 2 tahun bagian paha belakang, belimbing wuluh, air, dan aquades.
Metode

Metode yang digunakan dalam penelitian ini adalah metode eksperimental dengan Rancangan Acak Lengkap (RAL) yang terdiri atas 4 perlakuan dan menggunakan 20 orang panelis secara hedonik (Kartika et al., 1988). Perlakuan yang digunakan adalah :

M0 $=$ Kontrol (tanpa marinasi)

M1 = Proses marinasi menggunakan larutan belimbing wuluh $30 \%$

M2 = Proses marinasi menggunakan larutan belimbing wuluh $60 \%$

M3 = Proses marinasi menggunakan larutan belimbing wuluh $90 \%$

Cara Kerja

Preparasi Daging Kambing

Daging kambing jantan yang berumur 2 tahun dipisahkan dari kulit, lemak dan tulang. Daging kambing kemudian dibersihkan dan dipotong-potong dengan ukuran $1 \mathrm{~cm}^{3}$ (Hafid dan Syam, 2009).

Preparasi Larutan Belimbing Wuluh

Belimbing wuluh diblender hingga halus, disaring dan diperas untuk kemudian dipisahkan air dan ampasnya. Air belimbing wuluh kemudian diambil sebanyak $30 \mathrm{ml}$ dilarutkan kedalam $70 \mathrm{ml}$ akuades (M1), $60 \mathrm{ml}$ kedalam $40 \mathrm{ml}$ akuades (M2) dan $90 \mathrm{ml}$ untuk dilarutkan kedalam $10 \mathrm{ml}$ aquades (M3) sehingga diperoleh masing-masing larutan belimbing wuluh dengan konsentrasi 30, 60 dan $90 \%(\mathrm{v} / \mathrm{v})$.

Marinasi Daging Kambing

Larutan belimbing wuluh yang telah disiapkan diambil sebanyak 30\% dari berat daging dan digunakan sebagai bahan marinasi. Daging kambing kemudian dimarinasi selama 30 menit, kemudian direbus selama 10 menit dengan suhu $100^{\circ} \mathrm{C}$ hingga matang. Daging yang telah matang kemudian diuji secara sensoris(Hafidet al., 2013).

\section{Uji Sensoris}

Uji sensoris dilakukan dengan menggunakan 20 orang panelis yang merupakan mahasiswa Universitas Sriwijaya. Panelis masing-masing diberikan 4 sampel penelitian dan lembar kusioner untuk kemudian melakukan pengujian sesuai dengan tingkat kesukaan menggunakan skor yang ada di dalam kuisioner sesuai dengan Tabel 1. 
Tabel 1. Skala Hedonik untuk uji kualitas sensoris daging kambing

\begin{tabular}{clllll}
\hline $\begin{array}{c}\text { Skala } \\
\text { Hedonik }\end{array}$ & \multicolumn{1}{c}{ Rasa } & \multicolumn{1}{c}{ Aroma } & \multicolumn{1}{c}{ Warna } & \multicolumn{1}{c}{ Tekstur } & \multicolumn{1}{c}{ Daya Terima } \\
\hline 1 & Tidak suka & Tidak suka & Tidak suka & Tidak suka & Tidak suka \\
2 & Kurang suka & Kurang suka & Kurang suka & Kurang suka & Kurang suka \\
3 & Netral & Netral & Netral & Netral & Netral \\
4 & Suka & Suka & Suka & Suka & Suka \\
\hline 5 & Sangat suka & Sangat suka & Sangat suka & Sangat suka & Sangat suka \\
\hline
\end{tabular}

Sumber: Soekarto(2002)

\section{Analisis Data}

Data hasil uji sensoris rasa, aroma, warna, tekstur dan daya terima dianalisa dengan uji Kruskal-Wallis menggunakan SPSS 16.0.

\section{HASIL DAN PEMBAHASAN}

Rata-rata nilai sensoris daging kambing yang dimarinasi dengan menggunakan larutan belimbing wuluh dapat dilihat pada Tabel 2 .

Tabel 2. Kualitas sensoris daging kambing yang dimarinasi menggunakan larutan belimbing wuluh

\begin{tabular}{cccccc}
\hline \multirow{2}{*}{ Perlakuan } & \multicolumn{5}{c}{ Rata-rata } \\
\cline { 2 - 6 } & Rasa & Warna & Aroma & Tekstur & Daya Terima \\
\hline M0 & $3,45 \pm 1,00$ & $3,80 \pm 1,15$ & $4,00 \pm 1,08$ & $3,30 \pm 1,17$ & $3,55 \pm 0,83$ \\
M1 & $3,40 \pm 1,19$ & $3,30 \pm 1,03$ & $3,35 \pm 1,09$ & $3,20 \pm 1,06$ & $3,20 \pm 1,06$ \\
M2 & $3,45 \pm 0,89$ & $3,45 \pm 0,94$ & $3,50 \pm 1,28$ & $3,45 \pm 0,89$ & $3,30 \pm 1,08$ \\
M3 & $3,55 \pm 1,10$ & $3,60 \pm 0,82$ & $3,55 \pm 1,23$ & $3,60 \pm 1,14$ & $3,45 \pm 0,94$ \\
\hline
\end{tabular}

Keterangan: M0 $=$ kontrol, M1 $=30 \%$ larutan belimbing wuluh, M2 $=60 \%$ larutan belimbing wuluh, M3 $=90 \%$ larutan belimbing wuluh

Rasa

Hasil analisa menunjukkan bahwa penggunaan larutan belimbing wuluh sebagai bahan marinasi daging kambing tidak berpengaruh nyata $(\mathrm{P}>0,05)$ terhadap rasa daging kambing. Rerata skor rasa daging kambing yaitu 3,40-3,55 yang berarti bahwa rasa daging kambing normal. Artinya penggunaan larutan belimbing wuluh hingga konsentrasi $90 \%$ tidak mengubah rasa dari daging kambing tersebut. Skor tertinggi adalah 3,55 yaitu daging kambing yang dimarinasi menggunakan larutan belimbing wuluh dengan konsentrasi 90\%, sedangkan skor terendah adalah 3,40 yang merupakan daging kambing yang dimarinasi menggunakan larutan belimbing wuluh sebanyak 30\%. Penggunaan belimbing wuluh sebanyak $90 \%$ sebagai bahan marinasi daging kambing memiliki skor rasa yang paling mendekati kontrol. Ini menunjukkan bahwa larutan belimbing wuluh dapat digunakan sebagai bahan marinasi daging kambing tanpa menurunkan kualitas rasa.

Rasa merupakan salah satu faktor penting dalam penerimaan suatu produk daging (Ismanto dan Subaihah, 2020). Rasa daging kambing tanpa marinasi dan dengan marinasi belimbing wuluh relatif sama atau tidak mengalami perubahan. Kandungan asam asetat yang tinggi didalam belimbing wuluh (Djafar $e t$ al., 2014) tidak mengubah rasa daging kambing. Rasa daging kambing masak dipengaruhi oleh tambahan bumbu yang digunakan. Penggunaan larutan belimbing wuluh sebagai bahan marinasi tidak berpengaruh terhadap rasa daging kambing karena pemasakan dilakukan dengan menggunakan air tanpa campuran larutan belimbing wuluh.

Warna

Hasil analisis statistik berdasarkan Tabel 2 diatas menunjukkan bahwa penggunaan larutan belimbing wuluh sebagai bahan marinasi tidak berpengaruh nyata $(\mathrm{P}>0,05)$ terhadap skor warna daging kambing apabila dibandingkan dengan kontrol (tanpa marinasi). Rerata skor rasa berada pada kisaran 3,30-3,80 yang berarti warna daging kambing netral mendekati disukai. Hal ini menunjukan bahwa penggunaan larutan belimbing wuluh sebagai bahan marinasi daging kambing tidak merubah warna asli daging kambing. 
Daging kambing yang direbus masingmasing pada perlakuan marinasi larutan belimbing wuluh maupun tanpa marinasi memiliki warna yang sama yaitu coklat pucat. Hal ini disebabkan oleh proses perebusan dilakukan setelah proses marinasi, sehingga warna daging menjadi sama. Hal ini sesuai dengan hasil penelitian Muzaifa (2013) dimana kandungan asam didalam belimbing wuluh akan menyebabkan warna daging mentah menjadi lebih pucat.

Menurut Nurwantoroet al. (2011) warna daging yang dimasak lebih didominasi oleh bumbu yang digunakan. Daging kambing pada penelitian ini direbus tanpa menggunakan bumbu tambahan sehingga warna yang dihasilkan menjadi relatif sama. Kandungan asam didalam belimbing wuluh juga tidak mempengaruhi warna daging kambing masak. Hal ini diduga karena proses pemasakan pada daging tanpa marinasi dan dengan marinasi dimasak dengan cara yang sama sehingga warna daging lebih dipengaruhi oleh suhu dan lama pemasakan.

\section{Aroma}

Hasil analisis statistik menunjukkan bahwa penggunaan larutan belimbing wuluh sebagai bahan marinasi tidak berpengaruh nyata $(\mathrm{P}>0,05)$ terhadap skor aroma daging kambing. Rerata skor berkisar antara 3,35 hingga 4,40 yang menunjukan penilaian panelis terhadap adalah netral dan suka terhadap aroma daging kambing. Skor tertinggi ada pada aroma daging tanpa marinasi dan yang terendah adalah aroma daging kambing yang dimarinasi menggunakan larutan belimbing wuluh sebanyak $30 \%$.

Aroma gurih daging kambing merupakan salah satu faktor kesukaan yang sangat diharapkan oleh panelis (Elvira,2011). Aroma gurih terbentuk dari adanya proses degradasi lemak ketika proses pemasakan berlangsung. Hal ini sejalan dengan pendapat Hadiwiyoto (1993) yang menyatakan bahwa kandungan peptida dan asam amino bebas serta asam lemak bebas merupakan senyawa-senyawa yang bersifat volatil yang mempengaruhi aroma daging.

\section{Tekstur}

Penggunaan larutan belimbing wuluh sebagai bahan marinasi daging kambing tidak berpengaruh nyata $(\mathrm{P}>0,05)$ terhadap tekstur daging. Rerata skor panelis berkisar antara 3,20 hingga 3,60 yang menunjukkan bahwa tekstur daging kambing netral dan disukai. Skor tertinggi adalah 3,60 yaitu daging kambing yang dimarinasi menggunakan larutan belimbing wuluh sebanyak $90 \%$ sementara skor terendah adalah 3,20 yaitu daging kambing yang dimarinasi menggunakan larutan belimbing wuluh sebanyak $30 \%$. Nilai keseluruhan skor tekstur daging kambing yang dimarinasi dengan larutan belimbing wuluh dibandingkan dengan tanpa marinasi (kontrol) adalah relatif sama.

Hasil ini menunjukkan bahwa tekstur daging kambing perlakuan dan kontrol relatif sama. Artinya penambahan larutan belimbing wuluh hingga konsentrasi $90 \%$ dapat mempertahankan tekstur daging kambing. Tekstur daging berkaitan dengan keempukan (Soeparno, 2009). Semakin empuk daging makan akan semakin tinggi residu dari jus daging yang tertinggal selama proses mengunyah berlangsung. Daging kambing pada penelitian ini dimasak dengan suhu dan lama pemasakan yang sama dan tanpa penambahn bumbu. Hal ini diduga menjadi hal utama yang menyebabkan rasa daging menjadi sama. Namun peningkatan nilai skor tekstur pada perlakuan marinasi menggunakan larutan belimbing wuluh dengan konsentrasi $90 \%$ menunjukkan bahwa terdapat pengaruh kandungan asam didalam belimbing wuluh terhadap keempukan daging.

\section{Daya Terima}

Berdasarkan hasil analisis statistik pada Tabel 2. diatas dapat diketahui bahwa skor daya terima daging kambing yang dimarinasi menggunakan larutan belimbing wuluh dengan konsentrasi hingga 90\% tidak berpengaruh nyata $(\mathrm{P}>0,05)$ dibandingkan dengan kontrol atau tanpa marinasi. Rerata skor daya terima berkisar antara 3,20-3,55 yang berarti netral mendekati disukai oleh panelis. Skor tertinggi 3,55 yaitu daging kambing tanpa marinasi dan skor terndah adalah 3,20 yang merupakan daging kambing dengan marinasi larutan belimbing wuluh dengan konsentrasi $30 \%$. Hasil analisa daya terima yang tidak berpengaruh nyata dipengaruhi oleh skor rasa, warna, aroma, dan tekstur daging kambing yang juga tidak berpengaruh nyata. 
Hasil daya terima secara keseluruhan menunjukkan bahwa penggunaan larutan belimbing wuluh hingga $90 \%$ sebagai bahan marinasi daging kambing memiliki skor nilai yang relatif sama dengan daging yang tidak dimarinasi (kontrol). Hal ini menunjukkan bahwa penggunaan belimbing wuluh sebagai bahan marinasi tidak menurunkan daya terima daging kambing, sehingga kualitas sensoris dapat dipertahankan.

\section{KESIMPULAN}

Penggunaan larutan belimbing wuluh sebagai bahan marinasi hingga 90\% memiliki rataan skor rasa, warna, aroma dan tekstur daging kambing yang realtif sama dengan kontrol. Hal ini menunjukkan bahwa larutan belimbing wuluh dapat digunakan sebagai bahan marinasi untuk mempertahankan kualitas sensoris daging kambing.

\section{UCAPAN TERIMA KASIH}

Terima kasih kepada Universitas Sriwijaya yang telah mendanai penelitian ini melalui LPPM Unsri. Terima kasih juga kepada Zultra Mandala selaku mahasiswa Prodi Peternakan, Fakultas Pertanian, Unsri yang telah membantu dalam pelaksanaan penelitian ini.

\section{DAFTAR PUSTAKA}

Djafar R, Harmain RM dan Dali FA. 2014. Efektivitas belimbing wuluh terhadap parameter mutu organoleptik dan $\mathrm{pH}$ ikan layang segar selama penyimpanan ruang. Jurnal Ilmiah Perikanan Dan kelautan. 2(1): 23-28.

Elvira S. 2011. Karakteristik Mutu Daging. Repository IPB. Bogor.

Hadiwiyoto S. 1993. Teknologi Pengolahan Hasil Perikanan. Jilid 1. Liberty. Yogyakarta.

Hafid H dan Syam A. 2009. Kualitas organoleptik daging kambing lokal dengan lama pelayuan dan cara pemasakan yang berbeda. Buletin Peternakan. 33 (3) : 178182.

Hafid H, Nuraini dan Inderawati. 2013. Pengaruh ekstrak buah nenas muda terhadap kualitas sensoris daging kerbau. Agriplus. 23(1): 18-23.
Ismanto A dan Subaihah S. 2020. Sifat fisik, organoleptik dan aktivitas antioksidan sosis ayam dengan penambahan ekstrak daun sirsak (Annona muricata I.). Jurnal Ilmu Peternakan dan Veteriner Tropis. 10(1). 45-54.

Kartika B, Hastuti P dan Supartono W. 1988. Pedoman Uji Indrawi Bahan Pangan. Universitas Gadjah Mada. Yogyakarta

Maruddin F. 2004. Kualitas daging sapi asap pada lama pengasapan dan penyimpanan. J. Sains Teknol. 4(2) : 83-90.

Muzaifa M. 2013. Perubahan karakteristik belimbing wuluh selama fermentasi asam sunti. Jurnal Teknologi dan Industri Pertanian Indonesia. 5(2): 7-11.

Naude RT dan Hofmeyr HS. 1981. Meat Production dalam Goat Production, C. Gall. Academic Press. New York.

Nurwantoro N, Bintoro VP, Legowo AM, Ambara LD, Prakoso A, Mulyani S and Purnomoadi A. 2011. Microbiological and physical properties of beef marinated with garlic juice. Journal of the Indonesian Tropical Animal Agriculture. 36 (3) : 166170.

Pursudarsono F, Rosyidi D dan Widati AS. 2015. Pengaruh perlakuan imbangan garam dan gula terhadap kualitas dendeng paru-paru sapi. Jurnal Ilmu dan Teknologi Hasil Ternak. 10(1) : 35-45.

Soekarto ST. 2002. Penilaian Organoleptik. Pusat Pengembangan Teknologi Pangan dan Hasil Pertanian. Institut Pertanian Bogor. Bogor.

Soeparno. 2009. Ilmu dan Teknologi Daging. Gadjah Mada University Press. Yogyakarta.

Subhadrabandhu S. 2001. Under-Utilized Tropical Fruits of Thailand, (Online), (ftp://ftp.fao.org/docrep/fao/fao/004/ab77 7e/ab777e00.pdf) diakses pada tanggal 2 Pebruari 2020.

Thomas ANS. 2007. Tanaman Obat Tradisional. Kanisius. Yogyakarta.

Wahyuni D, Yosi F dan Muslim G. 2019. Kualitas sensoris daging kambing yang dimarinasi menggunakan larutan mentimun (Cuccumis sativus L.). Jurnal Peternakan Sriwijaya. 8(1) : 14-20. 